18

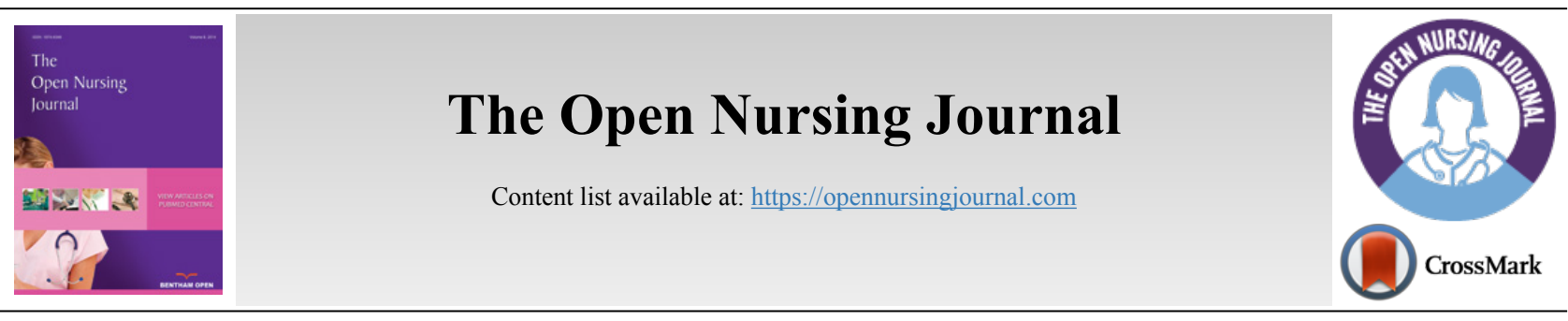

REVIEW ARTICLE

\title{
m-Health in the Surgical Context: Prospecting, Review and Analysis of Mobile Applications
}

Alvaro F. L. de Sousa ${ }^{1,2,}$, Lucas L. Bim ${ }^{2}$, Guilherme Schneider ${ }^{2}$, Paula R. de Souza Hermann ${ }^{2}$, Denise de Andrade ${ }^{2}$ and Inês Fronteira ${ }^{2}$

${ }^{1}$ Universidade de São Paulo, Ribeirão Preto College of Nursing, Ribeirão Preto, São Paulo, Brazil

${ }^{2}$ Universidade NOVA de Lisboa, Institute of Hygiene and Tropical Medicine, Lisboa, Portugal

\begin{abstract}
:
Background

m-Health initiatives can show an opportunity to improve the identification, prevention and management of certain diseases. Most health-care applications aim at chronic noncommunicable diseases care, and it is necessary to seek evidence from applications intended for surgical patient care, either before, during or after hospitalization.

Objective:

The study aims to identify and analyze, from the literature review and prospecting, applications for smartphones developed to assist the surgical patient.

Methods:

A descriptive-exploratory study developed in two sequential phases. The first one corresponded to an integrative review of the literature in the databases PubMed, Web of Knowledge, Europe PMC database and Cumulative Index to Nursing and Allied Health Literature database. The second phase corresponded to an exploration of applications in the European Patent Office, United States Patent and Trademark Office (USPTO), Free Patents Online, Canadian Intellectual Property Office and World Intellectual Property Organization. In both phases, we do not restrict the results by year of publication/registration or language. At each stage, the selected studies/patents were analyzed and pre-selected, according to the inclusion and exclusion criteria, by reading their titles and abstracts. Subsequently, we analyzed those with the potential of participation in the study, evaluating the answer to the research question, as well as the type of research, objectives, sample, method, outcomes, results and conclusion. Finally, the articles/patents record found were read in full.
\end{abstract}

Results

In the databases, 14 studies that presented some application for smartphone aimed at the surgical patient were selected. Most of them were in PubMed (64.3\%), published in English (100\%). Regarding origin, 28.6\% of the texts were from the United States of America, 14.3 from Sweden and 14.3 from Canada. On the other hand, in patent databases, 10 registries were selected, $60 \%$ in the USPTO patent base, hosted in hybrid systems (iPhone and Android) and developed in the last 5 years (2014-1018) (80\%). In general, there is a series of applications aimed at surgical patients, such as targets and/or users, mainly focused on the exchange of text and image messages but concentrated on assisting the physician/health team in the preparation of the patient during the procedure or post discharge. It is necessary to invest in the development of technologies that aim to monitor these patients, especially in post discharge.

\section{Conclusion}

The characteristics of applications indicate a strong hospital centered tendency in relation to its purpose, having the surgeon as the main user and the surgical patient as the main target. The applications are still focused on optimizing diagnostics or functions, and no initiatives are identified to monitor the patient in a non-hospital environment.

Keywords: m-Health, Surgical, Surgical complications, Mobile applications, Smart Phones, Management.

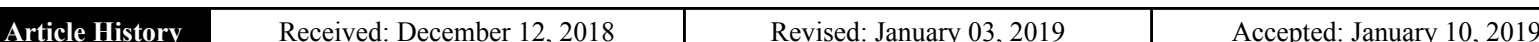




\section{INTRODUCTION}

In recent years, emerging information and mass communication technologies to improve or enable population health, commonly referred to as e-Health, have become commonplace and popular. The high potential for innovation and propagation of these technologies regarding the promotion and prevention of health in a remote way, mainly related to health education in hard-to-reach populations offers a unique opportunity for patients who need continuous monitoring, such as the surgical patient [1].

Recently, such initiatives have gained a powerful ally in this process: smartphones and all their mobile technological input, giving rise to the M-health phenomenon (mobile health). The popularization of smartphones represented a technological revolution of greater impact by being associated with the internet and social networks. These "smart phones" have enough technology to establish information flow including the exchange of audio messages, text and high-resolution photographic files [1 - 3]. By basing most of its tasks on applications (apps) with attractive, intuitive and user-friendly interfaces, visual and auditory features, as well as being able to be downloaded on a variety of platforms, smartphones are increasingly gaining space in the health system users/patients.

Initially, applications for M-health purposes performed the function of professional support, mainly related to the aid of diagnostics, therapeutic approaches and prescriptions of medicines using specific sensors for such purposes. Gradually, this function has been overcome, and the new applications developed are directed to health monitoring, reducing the distance between the patient and the healthcare team [4].

However, a recent study [5] shows that most health-care applications developed are focused on chronic noncommunicable diseases (CNCD), especially in Brazil, and it is necessary to seek evidence of applications aimed at surgical patient care, whether before, during or after hospitalization.

Thus, this study aims to identify and analyze, from the literature review and prospection, applications for smart phones developed to assist the surgical patient.

\section{METHOD}

\subsection{Type of Study}

This is a descriptive-exploratory study [6], conducted in two sequential phases: integrative literature review and application exploration.

Integrative Review (IR) is an important resource of evidence-based practice and provides systematic techniques to summarize the past of given literature, providing a comprehensive understanding of a given phenomenon [7]. On the other hand, studies on technology prospecting refer to activities of technology determination focused on technological changes in functional capacity, or on time and meaning of an

\footnotetext{
Address correspondence to this author at Av. dos Bandeirantes, 3900, 14040-902, Ribeirão Preto, São Paulo, Brazil; E-mails: alvarosousa@usp.br and sousa.alvaromd@gmail.com
}

innovation. This type of study aims at incorporating information into the technology management process, and thus to predict possible future states of the technology or conditions that affect its contribution to established goals [8].

Therefore, prospecting studies are useful for presenting the current state-of-the-art of a certain technological area, and for generating information about its trajectory, future and market trends, as well as the perception of weaknesses in certain areas [9]. Thus, they portray what is being recently done and point out the gaps that still have to be fulfilled. Nowadays, these studies constitute fundamental components to increase the capacity of anticipation and to stimulate the organization of innovation systems, transcending the business scope, for the academic environment.

In order to identify information or mass communication /eHealth technologies aimed at surgical patient care, we initially performed an integrative review of the literature (IR) [7], followed by a search for patents and software registration (technological prospecting) [8], according to the protocol presented below:

\subsubsection{Step 1: Integrative Review}

The elaboration of this stage included: definition of the research object; establishment of inclusion and exclusion criteria for sample selection; definition of the information to be extracted from the selected articles; analysis and discussion of results [7].

Thus, according to the adopted framework [7], we defined the mobile applications for smartphones developed to assist the surgical patient as a research object. We then used MeSh descriptors to search the PubMed databases through the PubMed portal of the National Library of Medicine, Web of Knowledge (WoK) and Europe PMC, and, through the combination of descriptors and keywords, the Cumulative Index to Nursing and Allied Health Literature (CINAHL).

The defined inclusion criteria were: primary studies [7], with full-text available, published until December 2016, in any language. Chapters of books, doctoral theses, master's dissertations and technical reports were excluded from the initial search. The research was conducted from February 1st to the 15th, 2017 and was carried out simultaneously by two researchers with expertise in the subject and method.

We used the descriptors: Surgical; Patients; and Mobile Phone applications. The keywords and descriptors belonging to the same category were separated by "OR" and between them by "AND". The terms used during the survey were classified by the database:

\subsubsection{PubMed, Web of Science e Europe PMC (Mesh descriptors)}

Surgical procedures, operative OR surgical AND procedures AND operative OR operative surgical procedures OR surgical AND patients OR patients AND cell phones OR cell AND phones OR cell phones OR mobile AND phone OR mobile phone AND applications. 


\subsubsection{CINAHL (CINAHL titles)}

Mobile Applications AND Patient OR Surgical OR Surgical Patients.

The analysis for selection of the studies was carried out in three phases, namely:

[1] In the first phase, the selected studies in the databases were analyzed and pre-selected according to the inclusion and exclusion criteria, by reading their titles and abstracts. If the article did not have an abstract or it did not allow the exclusion or inclusion of the article, the full article was read. We obtained 36 studies from PubMed, 04 from CINAHL, 33 from Europe PMC and 10 from the Web of Science, totaling 83 studies.

[2] In the second phase, the studies were analyzed regarding the potential of inclusion in the study, evaluating the answer to the question of research, as well as its type, objectives, sample, method, outcomes, results and conclusion, resulting in 18 studies.

[3] The third phase consisted of the complete reading of the 18 studies, aiming to collect data specific to the study objectives, which resulted in 14 studies selected for the research (Fig. 1). This step was performed by two researchers. Meetings were held for discussion and consensus among resear- chers about the inclusion or exclusion of each study in the research.

\subsubsection{Step 2: Technology Prospecting}

This stage of the study was carried out after identifying the countries that had the greatest production in the subject (results of the integrative review), to define which patent bases could be included. Thus, we carried out systematized and simultaneous searches in the main world patent bases, namely: European Patent Office (Espacenet), United States Patent and Trademark Office (USPTO), Free Patents Online (FPO), Canadian Intellec- tual Property Office (CIPO), and World Intellectual Property Organization (WIPO), using the keywords "Application" AND "Surgical Patient."

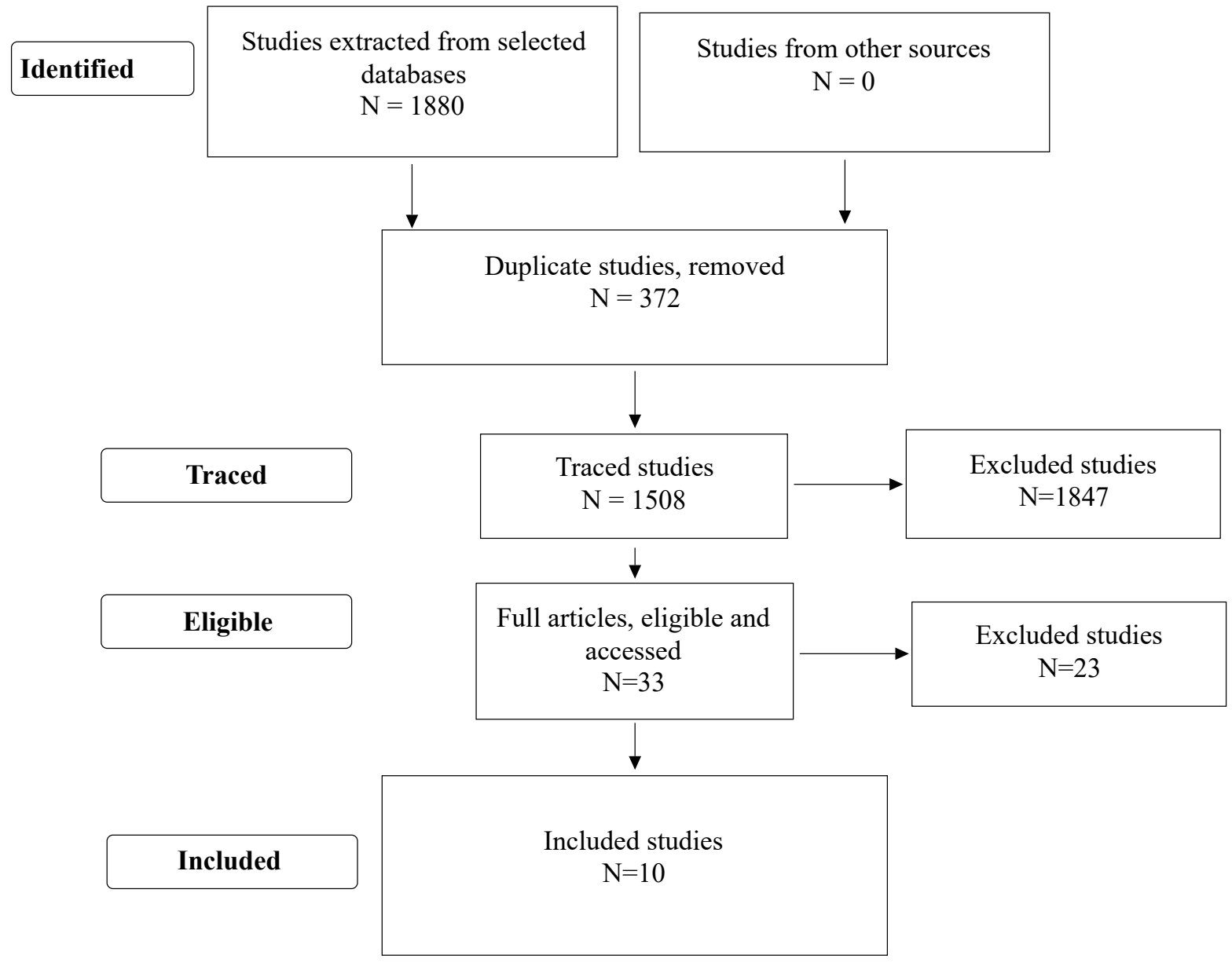

Fig. (1). Flowchart for selection of studies retrieved from databases. 


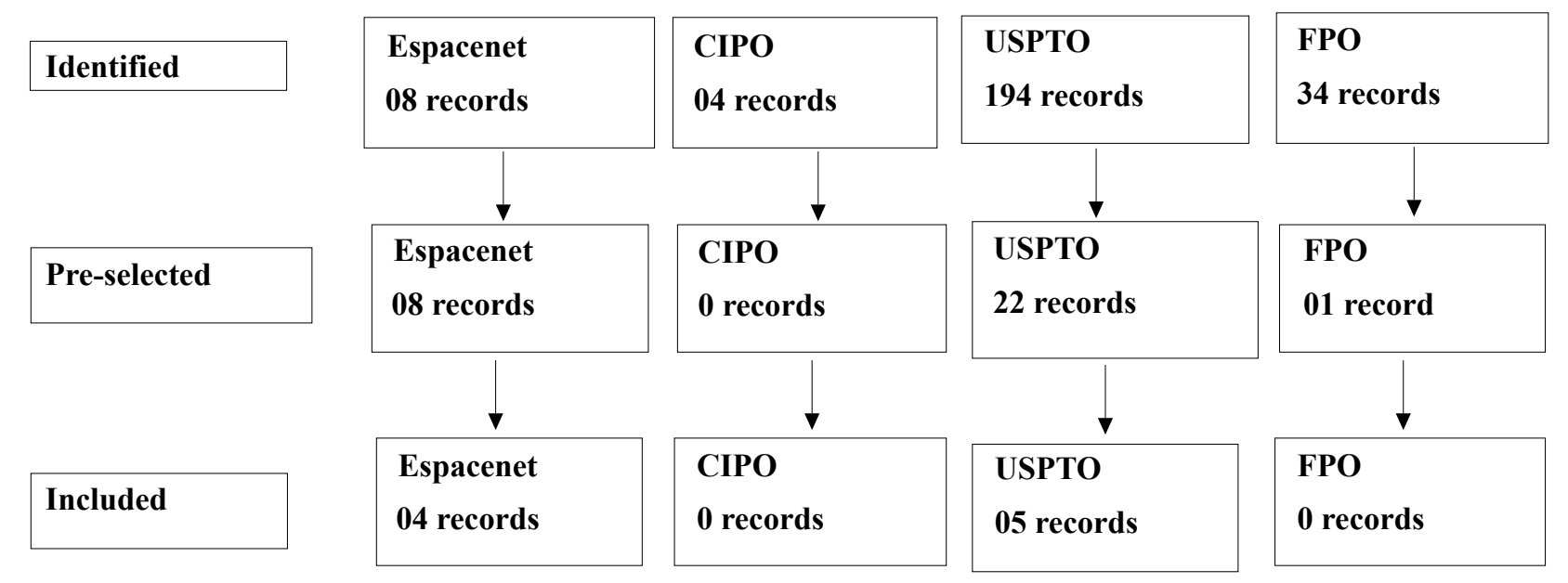

Notes: European Patent Office (Espacenet), United States Patent and Trademark Office (USPTO), Free Patents Online (FPO), Canadian Intellectual Property Office (CIPO), and World Intellectual Property Organization (WIPO).

Fig. (2). Flowchart of search in the selected patent bases.

The flowchart for search is described in Fig. (2).

\subsection{Classification of Mobile Applications}

We ranked the selected apps according to the classification of the main e-Health initiatives of the World Health Organization [10]:

[I] Call centers in medical care;

[II] Free emergency telephone services;

[III] Emergency applications for public health;

[IV] Mobile telemedicine services;

[V] Phone reminders;

[VI] Community mobilization for health promotion;

[VII] Treatment compliance initiatives;

[VIII] Patient Records Systems;

[IX] Systems of initiatives for information;

[X] Applications for patient monitoring;

[XI] Mobile devices for health research;

[XII] Surveillance system;

[XIII] Awareness systems;

[XIV] Decision support systems.

\subsection{Data Analysis}

The data were qualitatively analyzed by the researchers and presented in Tables $\mathbf{1}$ and $\mathbf{2}$ and in Figs. (1 and 2). The primary studies selected in the databases were analyzed for their main objective. The application presented in each study was evaluated for the name, characteristics and functions, availability for the main systems (iOS, Android and Windows Phone), country where it was developed, target population and user.

On the other hand, patent registrations were analyzed descriptively according to the information retrieved from the patent bases. We registered project title, name of the proposed application, origin where it was retrieved, publication number, year of registration and main characteristics.

\subsection{Ethical Aspects}

This research exempted the evaluation by an ethics committee because it did not involve human beings, according to the dispositions in the national ordinances 466/12 and $510 / 16$.

\section{RESULT}

In the review stage of the literature, 14 primary studies were included, didactically ordered and identified from A1 to A14. All studies (100\%) were in English, with a concentration in the year 2015 (42.8\%), in the PubMed database (71.4\%), developed in the United States of America (28.6\%). The applications developed were hosted on hybrid systems (IPhone and Android). In general, there are a series of applications aimed at surgical patients, as targets and/or users, mainly focused on the exchange of text and image messages but concentrated on assisting the physician/health team in the preparation of the patient during the procedure or post discharge. 


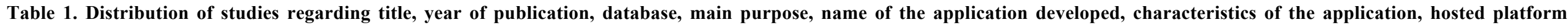
classification, country, target and users.

\begin{tabular}{|c|c|c|c|c|c|c|c|c|}
\hline $\begin{array}{l}\text { Order } \\
\text { Title } \\
\text { Year }\end{array}$ & Database & Primary Objective & $\begin{array}{c}\text { Application } \\
\text { Name }\end{array}$ & $\begin{array}{l}\text { Characteristics } \\
\text { of the application }\end{array}$ & Available? & Classification* & Country & Target and users \\
\hline $\begin{array}{c}\text { A1 } \\
\text { Usability of mobile technology to } \\
\text { screen for drug-drug interactions in } \\
\text { kidney transplant patients (2014) } \\
{[11]}\end{array}$ & PubMed & $\begin{array}{l}\text { To test a system of investigation to reduce } \\
\text { the aggravations related to drug } \\
\text { interactions in patients undergoing renal } \\
\text { transplantation. }\end{array}$ & $\begin{array}{c}\text { Not specified, } \\
\text { however, it } \\
\text { was aided by: } \\
\text { SMS gateway } \\
\text { service } \\
\text { (Twilio TM; } \\
\text { www.twilio. } \\
\text { com). }\end{array}$ & $\begin{array}{l}\text { Inquiry by SMS for precaution of drug } \\
\text { interactions between drugs already used } \\
\text { and prescribed, based on the receipt and } \\
\text { response to text messages sent by users. }\end{array}$ & \begin{tabular}{|c|} 
Yes \\
iOS, \\
Android and \\
Windows \\
Phone
\end{tabular} & \begin{tabular}{|c|} 
IV \\
Phone reminders
\end{tabular} & $\begin{array}{l}\text { United } \\
\text { States }\end{array}$ & $\begin{array}{l}\text { Users: Transplanted patients } \\
\text { (kidney). } \\
\text { Target: Prevent adverse } \\
\text { reactions caused by drug } \\
\text { interactions. }\end{array}$ \\
\hline $\begin{array}{c}\text { A2 } \\
\text { Smartphone versus knee ligament } \\
\text { arthrometer when size does not } \\
\text { matter. } \\
(2014)[12] \\
\end{array}$ & PubMed & $\begin{array}{c}\text { To test the use of an app to measure } \\
\text { anterior translation of tibia (ATT) in } \\
\text { anterior cruciate ligament (ACL) cruciate } \\
\text { ligaments. }\end{array}$ & SmartJoint & $\begin{array}{c}\text { The app is able to record the Lachman } \\
\text { measurement and manual test one or } \\
\text { more times. The measurement is } \\
\text { expressed in the application screen in } \\
\text { millimeters. }\end{array}$ & $\begin{array}{l}\text { Yes. } \\
\text { iOS and } \\
\text { Android }\end{array}$ & \begin{tabular}{|c|} 
XIII \\
Decision support \\
systems
\end{tabular} & Italy & \begin{tabular}{|} 
Target: Patients from poor and \\
reconstructed knee surgeries \\
Users: Doctors
\end{tabular} \\
\hline $\begin{array}{c}\text { A3 } \\
\text { A smartphone app to assist scalp } \\
\text { localization of superficial } \\
\text { supratentorial lesions } \\
\text { (2016) [13] }\end{array}$ & PubMed & $\begin{array}{l}\text { Test an application in order to assist the } \\
\text { location of the scalp region more adequate } \\
\text { to perform the incision in the planning of } \\
\text { the surgery and to compare with already } \\
\text { established neuronavigation systems. }\end{array}$ & SINA & $\begin{array}{l}\text { The application can identify images } \\
\text { through the camera, or photos, and } \\
\text { compare with anatomical models and } \\
\text { MRI images. }\end{array}$ & $\begin{array}{l}\text { Yes. } \\
\text { iOS }\end{array}$ & $\begin{array}{c}\text { III } \\
\text { Mobile } \\
\text { Telemedicine } \\
\text { Services }\end{array}$ & Australia & $\begin{array}{c}\text { Users: surgeons } \\
\text { Target: Cranial Surgery } \\
\text { Patients }\end{array}$ \\
\hline $\begin{array}{c}\text { A4 } \\
\text { Symptoms and self-care following } \\
\text { pancreaticoduodenectomy: } \\
\text { Perspectives from patients and } \\
\text { healthcare professionals - } \\
\text { Foundation for an interactive ICT } \\
\text { application. } \\
\text { (2016, Epub) [14] }\end{array}$ & $\begin{array}{l}\text { Web Of } \\
\text { Science }\end{array}$ & $\begin{array}{c}\text { Develop an application for the post- } \\
\text { discharge management (up to } 6 \text { months) } \\
\text { of patients in the postoperative period of } \\
\text { Pancreatoduodenectomy. }\end{array}$ & Not specify & $\begin{array}{l}\text { The manuscript does not describe the } \\
\text { application, it only presents } \\
\text { qualitatively the perceptions of the } \\
\text { users. }\end{array}$ & $\begin{array}{c}\text { Not } \\
\text { applicable }\end{array}$ & \begin{tabular}{|c|} 
IX \\
Applications for \\
patient monitoring
\end{tabular} & Sweden & $\begin{array}{l}\text { User: patient of surgery } \\
\text { Pancreatoduodenectomy. } \\
\text { Target: Surgery patient } \\
\text { Pancreatoduodenectomy }\end{array}$ \\
\hline $\begin{array}{c}\text { A5 } \\
\text { Electronic wound monitoring after } \\
\text { ambulatory breast cancer surgery: } \\
\text { Improving patient care and } \\
\text { satisfaction using a smartphone app } \\
\text { (2016, Epub) [15] }\end{array}$ & $\begin{array}{l}\text { Web Of } \\
\text { Science }\end{array}$ & $\begin{array}{c}\text { Compare the follow-up of the surgical } \\
\text { wound after the mastectomy surgery in a } \\
\text { traditional way and through an electronic } \\
\text { application. }\end{array}$ & MEDEO & $\begin{array}{c}\text { Patients were asked to take a picture of } \\
\text { their wounds } 1,3,7 \text { and } 14 \text { days after } \\
\text { surgery and send them to the surgeon } \\
\text { using the smartphone. Patients could } \\
\text { ask questions and raise concerns and } \\
\text { the surgeon would respond within } 24 \\
\text { hours. }\end{array}$ & \begin{tabular}{|c|} 
Yes. \\
Android and \\
iOS
\end{tabular} & \begin{tabular}{|c|} 
IX \\
Applications for \\
patient monitoring
\end{tabular} & $\begin{array}{l}\text { United } \\
\text { States }\end{array}$ & $\begin{array}{l}\text { Target: patients with breast } \\
\text { cancer. } \\
\text { User: patients with breast } \\
\text { cancer. }\end{array}$ \\
\hline
\end{tabular}




\begin{tabular}{|c|c|c|c|c|c|c|c|c|}
\hline $\begin{array}{l}\text { Order } \\
\text { Title } \\
\text { Year }\end{array}$ & Database & Primary Objective & $\begin{array}{l}\text { Application } \\
\text { Name }\end{array}$ & $\begin{array}{l}\text { Characteristics } \\
\text { of the application }\end{array}$ & Available? & Classification* & Country & Target and users \\
\hline $\begin{array}{c}\text { A6 } \\
\text { Improving the quality of } \\
\text { colonoscopy bowel preparation using } \\
\text { a smartphone application: A } \\
\text { randomized trial } \\
\text { (2015) [16] }\end{array}$ & PubMed & $\begin{array}{c}\text { This study aimed to evaluate whether an } \\
\text { app designed to increase the quality of } \\
\text { intestinal preparation and patient } \\
\text { satisfaction using different educational } \\
\text { tools could improve bowel cleansing in } \\
\text { patients undergoing colonoscopy. As } \\
\text { secondary objectives, we evaluated the } \\
\text { effect of the app on patient satisfaction }\end{array}$ & $\begin{array}{c}\text { Bowel } \\
\text { colonoscopy }\end{array}$ & \begin{tabular}{|} 
The app assists in gut preparation by \\
explaining the procedure, providing tips \\
and examples of a low-fiber diet, and \\
displaying quality photos of the \\
preparation and showing an educational \\
video explaining how to prepare the \\
purgative solution. At the end, the \\
patient obtains a check list to confirm \\
compliance with all steps. \\
\end{tabular} & Yes, iOS. & Can not sort. & Spain & $\begin{array}{l}\text { Target and user: preoperative } \\
\text { colonoscopy patients }\end{array}$ \\
\hline $\begin{array}{c}\text { A7 } \\
\text { Feasibility of Smartphone-Based } \\
\text { Education Modules and Ecological } \\
\text { Momentary Assessment/Intervention } \\
\text { in Pre-bariatric Surgery Patients. } \\
\text { (2015) [17] }\end{array}$ & PubMed & $\begin{array}{l}\text { Evaluate the feasibility of using a } \\
\text { smartphone app with momentary } \\
\text { ecological evaluation functionality to } \\
\text { prepare patients for bariatric surgery }\end{array}$ & Same & $\begin{array}{l}\text { The components of the application } \\
\text { made it possible to educate, evaluate, } \\
\text { and send brief messages covering key } \\
\text { domains of lifestyle. The messages } \\
\text { were appropriate for the lifestyle } \\
\text { introduced by the participant in the } \\
\text { application, and, depending on the } \\
\text { responses, the app sent messages of } \\
\text { support about lifestyle change, } \\
\text { including tips and alternatives to keep } \\
\text { the change. }\end{array}$ & $\begin{array}{c}\text { Android and } \\
\text { iOS }\end{array}$ & \begin{tabular}{|c|} 
IX \\
Applications for \\
patient monitoring
\end{tabular} & $\begin{array}{l}\text { United } \\
\text { States }\end{array}$ & $\begin{array}{l}\text { Target and users: People } \geq 18 \\
\text { years submitted to evaluation } \\
\text { for primary laparoscopic } \\
\text { bariatric surgery, for the } \\
\text { management of medical } \\
\text { complications }\end{array}$ \\
\hline $\begin{array}{c}\mathrm{A} 8 \\
\text { Using a novel wireless system for } \\
\text { monitoring patients after the atrial } \\
\text { fibrillation ablation procedure: the } \\
\text { iTransmit study } \\
\text { (2015) [18] }\end{array}$ & PubMed & $\begin{array}{c}\text { To assess the feasibility and efficacy of } \\
\text { technology to monitor patients after atrial } \\
\text { fibrillation and to evaluate patients' } \\
\text { feedback on its usability. }\end{array}$ & $\begin{array}{l}\text { AliveCor } \\
\text { (AHM). }\end{array}$ & \begin{tabular}{|c|} 
This technology incorporates electrodes \\
in an iPhone case that converts \\
electrical signals from fingertips to \\
ultrasound signals; these signals are \\
then transmitted to the smartphone \\
microphone and an electrocardiogram \\
(ECG). The trace can then be \\
transferred to a wireless browser for \\
immediate remote interpretation. \\
\end{tabular} & Not specify. & $\begin{array}{c}\text { IX. } \\
\text { Applications for } \\
\text { patient monitoring }\end{array}$ & $\begin{array}{l}\text { United } \\
\text { States }\end{array}$ & $\begin{array}{l}\text { Target and users: Patients } \\
\text { after the atrial fibrillation } \\
\text { ablation procedure. }\end{array}$ \\
\hline $\begin{array}{c}\text { A9 } \\
\text { Intracranial ventricular catheter } \\
\text { placement with a smartphone } \\
\text { assisted instrument } \\
\text { (2015) [19] }\end{array}$ & PubMed & $\begin{array}{l}\text { To develop an app to assist physicians in } \\
\text { the correct positioning of the ventricular } \\
\text { catheter in neurosurgical patients. }\end{array}$ & $\begin{array}{l}\text { Angle Meter } \\
\text { PRO }\end{array}$ & $\begin{array}{c}\text { It is used to perform the measurements } \\
\text { within the respective image using the } \\
\text { software application (Thomale Guide } \\
\text { App, Miethke-Aesculap, Germany) }\end{array}$ & Yes, iOS & $\begin{array}{c}\text { III } \\
\text { Mobile } \\
\text { Telemedicine } \\
\text { Services: }\end{array}$ & Germany & $\begin{array}{c}\text { Target: neurosurgical patients } \\
\text { for placement of ventricular } \\
\text { catheter } \\
\text { User: surgeons }\end{array}$ \\
\hline $\begin{array}{c}\text { A10 } \\
\text { Pilot implementation and user } \\
\text { preferences of a Bariatric After-care } \\
\text { application } \\
\text { (2015) [20] }\end{array}$ & PubMed & $\begin{array}{l}\text { To illustrate the development of a } \\
\text { smartphone app and highlight user } \\
\text { preferences regarding in-app features }\end{array}$ & $\begin{array}{l}\text { Bariatric } \\
\text { After-care } \\
\text { smartphone }\end{array}$ & $\begin{array}{c}\text { The software was able to evaluate and } \\
\text { monitor bariatric patients. }\end{array}$ & $\begin{array}{c}\text { Yes } \\
\text { Android and } \\
\text { iOS }\end{array}$ & $\begin{array}{c}\text { III } \\
\text { Mobile } \\
\text { Telemedicine } \\
\text { Services: }\end{array}$ & Canada & $\begin{array}{l}\text { Target and user: bariatric } \\
\text { surgery patients }\end{array}$ \\
\hline
\end{tabular}




\begin{tabular}{|c|c|c|c|c|c|c|c|c|}
\hline $\begin{array}{l}\text { Order } \\
\text { Title } \\
\text { Year }\end{array}$ & Database & Primary Objective & $\begin{array}{c}\text { Application } \\
\text { Name }\end{array}$ & $\begin{array}{c}\text { Characteristics } \\
\text { of the application }\end{array}$ & Available? & Classification* & Country & Target and users \\
\hline \begin{tabular}{|c|} 
A11 \\
Online and smartphone-based \\
cognitive behavioral therapy for \\
bariatric surgery patients: Initial pilot \\
study \\
(2015) [21]
\end{tabular} & PubMed & $\begin{array}{c}\text { To determine if bariatric surgery patients } \\
\text { will be receptive to an app-based } \\
\text { intervention. }\end{array}$ & \begin{tabular}{|c|} 
Bariatric \\
Surgery \\
Online CBT
\end{tabular} & \begin{tabular}{|c|} 
Includes scales, for pre and post \\
evaluation. Contains a material for \\
reading: "Nutrition after Bariatric \\
Surgery," as well as intervention \\
protocol: Cognitive Behavior Model of \\
Overeating.
\end{tabular} & \begin{tabular}{|c|} 
Yes \\
Android and \\
iOS
\end{tabular} & $\begin{array}{c}\text { III } \\
\text { Mobile } \\
\text { Telemedicine } \\
\text { Services: }\end{array}$ & Canada & $\begin{array}{l}\text { User and target: bariatric } \\
\text { surgery patients }\end{array}$ \\
\hline \begin{tabular}{|c|} 
A12 \\
Health information: What can mobile \\
phone assessments add? \\
(2012) [22]
\end{tabular} & $\begin{array}{l}\text { Europe } \\
\text { PMC }\end{array}$ & $\begin{array}{c}\text { To investigate whether the app created } \\
\text { could be used as a basis to continually } \\
\text { document patients' health information in } \\
\text { real time and provide conditions for } \\
\text { individual pain management after } \\
\text { cholecystectomy and hysterectomy } \\
\text { procedures. }\end{array}$ & Medical & $\begin{array}{c}\text { The application is used as means of } \\
\text { communication between health } \\
\text { professionals and patients. It is possible } \\
\text { for the professional to register a patient } \\
\text { and install the app on his cell phone, to } \\
\text { keep counted, to send messages, and to } \\
\text { leave pre-formulated questionnaires. }\end{array}$ & \begin{tabular}{|c|} 
Yes \\
Android and \\
iOS
\end{tabular} & $\begin{array}{c}\text { XI. } \\
\text { Surveillance } \\
\text { system }\end{array}$ & Sweden & Patients after cholecystectomy \\
\hline $\begin{array}{c}\text { A13 } \\
\text { Measuring physical activity in a } \\
\text { cardiac rehabilitation population } \\
\text { using a smartphone-based } \\
\text { questionnaire } \\
\text { (2013) [23] }\end{array}$ & $\begin{array}{l}2013 \\
\text { Europe } \\
\text { PMC }\end{array}$ & $\begin{array}{l}\text { To determine the convergent validity of a } \\
\text { MobilePAL against accelerometry in } \\
\text { people with cardiovascular disease (CVD) } \\
\text { and to compare how the MobilePAL } \\
\text { questionnaire performed compared to the } \\
\text { commonly used Selfrecall International } \\
\text { Physical Activity Questionnaire (IPAQ) } \\
\end{array}$ & MobilePAL & \begin{tabular}{|c|} 
Adapted the original questionnaire \\
(Javabased) to cell phone \\
(Smartphone). Participants did not need \\
to chip, and the results were exported to \\
an excel sheet. Collected questions \\
about physical activity,
\end{tabular} & Android & \begin{tabular}{|c|} 
IX. \\
Applications for \\
patient monitoring
\end{tabular} & \begin{tabular}{|c|} 
New \\
Zealand
\end{tabular} & $\begin{array}{c}\text { Target: physicians } \\
\text { Users: cardiac rehabilitation } \\
\text { patients }\end{array}$ \\
\hline \begin{tabular}{|c|} 
A14 \\
The use of telemedicine in burn care: \\
development of a mobile system for \\
TBSA documentation and remote \\
assessment \\
(2013) [24]
\end{tabular} & $\begin{array}{l}2014 \\
\text { Europe } \\
\text { PMC }\end{array}$ & $\begin{array}{l}\text { Demonstrate the technical background and } \\
\text { methodologies for remotely transferring } \\
\text { mobile data using apps. In addition to } \\
\text { investigating the accuracy of the } \\
\text { assessment among experts on burn } \\
\text { patients and their accuracy compared to a } \\
\text { method of surface estimation and } \\
\text { computerized documentation. }\end{array}$ & BurnCase 3D & \begin{tabular}{|c|} 
To collect information about burn \\
characteristics in burn patients who \\
underwent surgical procedures. It \\
shows a 3D virtual model of the patient, \\
and their burned areas. It also allows to \\
collect photos of the burn. Information \\
is sent from the app to the dekstop \\
version. The app stores and organizes \\
data for all patients.
\end{tabular} & $\begin{array}{c}\text { Yes, } \\
\text { Android }\end{array}$ & \begin{tabular}{|c|} 
XIII \\
Decision support \\
systems
\end{tabular} & Austria & $\begin{array}{l}\text { Target: burned patients } \\
\text { User: physicians }\end{array}$ \\
\hline
\end{tabular}


Table 2. Distribution of selected patents according to title, base, publication number, year and objective.

\begin{tabular}{|c|c|c|c|c|}
\hline Title & Base & $\begin{array}{c}\text { Publication } \\
\text { number }\end{array}$ & Year & Abstract \\
\hline $\begin{array}{l}\text { System, method and apparatus for } \\
\text { post-operative bariatric weight } \\
\text { loss performance tracking }\end{array}$ & Espacenet & US20160324468 & 2016 & $\begin{array}{l}\text { Mobile application developed to describe patient's weight loss after a } \\
\text { bariatric surgical procedure compared to a reference curve. By having a } \\
\text { reference curve for the patient to perform self-comparison, the application } \\
\text { can potentially encourage the user to strive to cope or overcome the } \\
\text { average weight loss over time, resulting in better patient outcomes. }\end{array}$ \\
\hline $\begin{array}{l}\text { Augmented Reality Imaging } \\
\text { System for Cosmetic Surgical } \\
\text { Procedures }\end{array}$ & USPTO & US20170119471 & 2016 & $\begin{array}{l}\text { In a breast augmentation procedure, a virtual breast image is generated and } \\
\text { superimposed on a target marker covering a patient's actual breasts, so that } \\
\text { the patient can see her real body with virtual breasts where her actual } \\
\text { breasts are. The patient sees this augmented reality image on a mobile } \\
\text { device, smartphone, tablet or computer. }\end{array}$ \\
\hline $\begin{array}{l}\text { System and method for providing } \\
\text { electronic access to patient-related } \\
\text { surgical information }\end{array}$ & USPTO & WO2013006234 & 2014 & $\begin{array}{l}\text { System capable of establishing communication between patients, surgeons } \\
\text { and the family during elective surgeries of great duration. The system has } \\
\text { audio and video and has been tested on children. }\end{array}$ \\
\hline $\begin{array}{l}\text { Operating room management } \\
\text { system with mobile app }\end{array}$ & Espacenet & WO2014059391 & 2014 & $\begin{array}{c}\text { Digital version of an anesthesia monitoring chart on a tablet or other } \\
\text { mobile device is used to record vital signs of the patient and other } \\
\text { important data during surgical operations. }\end{array}$ \\
\hline Mobile Patient Bed & USPTO & US20170119610 & 2015 & $\begin{array}{l}\text { Bed adapted and remotely controlled through a smartphone application that } \\
\text { can be used to move a patient between at least two places during a medical- } \\
\text { surgical procedure. It comprises an interface configured to selectively } \\
\text { couple the mobile patient bed to at least one medical system and at least } \\
\text { one processor configured to receive a medical system command. The } \\
\text { command can be given by voice, avoiding contact with the smartphone. }\end{array}$ \\
\hline $\begin{array}{c}\text { Holistic hospital patient care and } \\
\text { management system and method } \\
\text { for enhanced risk stratification }\end{array}$ & Espacenet & EP3129945 & 2014 & $\begin{array}{l}\text { A holistic hospital patient care and management system comprising a data } \\
\text { store capable of receiving and storing patient data, including both clinical } \\
\text { and non-clinical data. It operates with distributed sensors in medical and } \\
\text { social service facilities and is configured to detect a plurality of markers } \\
\text { that allow one to assess the location and status of real-time tracking. }\end{array}$ \\
\hline $\begin{array}{c}\text { Surgical location monitoring } \\
\text { system and method using natural } \\
\text { markers }\end{array}$ & USPTO & US20140128727 & 2012 & $\begin{array}{l}\text { Smartphone application capable of monitoring and planning a surgery } \\
\text { along with the medical team. It also crosses patients' data with surgical } \\
\text { room possibilities, monitors the patient's vital signs during surgery and can } \\
\text { assist the surgeon in delimiting the surgical site. }\end{array}$ \\
\hline $\begin{array}{l}\text { Controlled Communications } \\
\text { Mobile Digital System for } \\
\text { Physician-Healthcare System } \\
\text { Integration }\end{array}$ & USPTO & US20140039910 & 2012 & $\begin{array}{l}\text { The application provides a mobile digital communication management } \\
\text { platform that integrates messaging capabilities with a hospital scheduling } \\
\text { system to facilitate quick and easy scheduling of medical procedures and } \\
\text { physician/provider consultations. The management system includes a } \\
\text { mobile digital smart device application that scans users, encrypts and } \\
\text { decrypts electronic messages, and transmits and receives electronic } \\
\text { messages. }\end{array}$ \\
\hline $\begin{array}{c}\text { System and method for } \\
\text { facilitating delivery of patient } \\
\text { care }\end{array}$ & Espacenet & WO2015084743 & 2013 & $\begin{array}{l}\text { Surgical patient monitoring application based on a clinical and } \\
\text { standardized protocol of care. The application is able to provide indicative } \\
\text { information about the current clinical condition, as well as providing } \\
\text { instructions for patient-directed care that must be completed within a } \\
\text { period of time. }\end{array}$ \\
\hline
\end{tabular}

Most applications identified were centered on hospital care [11 - 14, 16, 18 - 24]. Also, regarding functions, the predominant applications were focused on "Mobile Telemedicine Services" [10] and "Applications for patient monitoring" [10].

Then, based on the finding that the main applications were developed in Europe and the United States of America, a systematized search was made on the chosen patent bases, as described in Fig. (2). Selected patents/application log were analyzed for title, base, publication number, year and objective. We identified 09 patents, predominant in the USPTO base, developed between 2012 and 2013 aiming to provide better patient care during surgery or hospitalization (Chart 02). This analysis showed that applications in development are still focused on patient care in the hospital, with the surgeon as the protagonist.

\section{DISCUSSION}

Our study is a pioneer in combining bibliographical strategies (integrative review) and bibliometric (technological prospecting) to identify mobile applications for assistance to the surgical patient. The mapping of the main mobile applications (apps) aimed at assisting surgical patients showed that there are initiatives. However, they are focused on the exchange of text and image messages between the medical team or on improving the care provided to the patient by the health team. The health mobility technologies (m-Health), benefitted by the advancement of smartphones, are presented as viable and important innovative solutions for health management of the population, however when their 
applicability is restricted to the hospital, professionals and institutions are underutilizing its potential.

Most applications identified were centered on hospital care [11 - 14, 16, 18 - 24]. Considering the specificities of the surgical patient, the establishment of more precise criteria to assist in the surgical approach contributes to the good development and reestablishment of the patient in relation to the surgery (A1,3,6,10,12). In addition, the existence of such technologies is an essential investment in improving communication between the health professionals, the patient and the family/ caregiver, reducing anxiety and other negative feelings, as well as having great value in the decision-making process, and educational aspects in health.

Also, when regarding functions, the predominant applications were focused on "Mobile Telemedicine Services" [10] and "Applications for patient monitoring" [10]. The first one corresponds to the use of functions common to mobile devices in health situations, such as communication between health professionals for consultation, help in diagnosis doubts, among others. It is useful in situations where there is a shortage of human resources and although preponderant in the literature, it is considered outdated by the range of resources currently available $[5,10]$.

On the other hand, applications for patient monitoring correspond to the use of technology to manage, monitor and treat a patient with some disease at a distance. It is especially used in chronic diseases such as diabetes, and in this case the exchange of necessary and important information can reduce the need for visits to health institutions and inform teams about emergency care $[5,10,25,26]$.

Although monitoring is provided remotely, the applications for this purpose, in general, were restricted to the monitoring of patients in the hospital itself $[27,28]$. However, due to mobility characteristics, the use of remote applications is promising, but little explored, especially in post-hospital discharge. Furthermore, the analysis of the patent database results shows that the applications in development are still focused on patient care in the hospital, with the surgeon as the protagonist.

Regarding Brazil, applications aimed at patient monitoring appear to be predominantly focused on a specific type of chronic disease, cardiac conditions, one of the most serious and severe health problems in the world, with no registry of apps aimed at surgical patient [5].

We believe that the use of m-Health may present a fundamental tool to improve surgical patient care at home, in order to identify early signs and symptoms of possible postdischarge complications. It must be considered that the management of this monitoring involves the health team, with an important role of the nurse. The training of this professional qualifies him/her to identify health-disease situations, subsidizing the prescription and implementation of concrete health actions in the promotion, prevention, recovery and rehabilitation in individual, family and community health, based on the systematization of his/her assistance [29].

Combining the results of studies involving the creation of technologies (Integrative Revision) with proposals still under development (technological prospecting) allows to identify gaps, to draw new initiatives and to complement the existing ones. Thus, our results contribute to bring the activities of human health even closer to initiatives of technology and innovation in health.

\section{CONCLUSION}

There is a range of mobile applications aimed at surgical patient care. The characteristics of these applications indicate a strong hospital-centered tendency regarding its purpose, having the surgeon as the main user and the surgical patient as the main target. The applications are still focused on optimizing diagnostics or functions, and no initiatives are identified to monitor the patient in a non-hospital environment.

\section{CONSENT FOR PUBLICATION}

Not applicable.

\section{CONFLICT OF INTEREST}

The authors declare no conflict of interest, financial or otherwise.

\section{ACKNOWLEDGEMENTS}

Declared none.

\section{REFERENCES}

[1] Olsen MR, Casado-Lumbreras C, Colomo-Palacios R. ADHD in eHealth-A systematic literature review. Procedia Comput Sci 2016; 100: 207-14.

[http://dx.doi.org/10.1016/j.procs.2016.09.142]

[2] Malvey DM, Slovensky DJ. Global mHealth policy arena: status check and future directions. mHealth 2017; $3: 41$.

[http://dx.doi.org/10.21037/mhealth.2017.09.03] [PMID: 291 84893]

[3] Klasnja P, Pratt W. Healthcare in the pocket: mapping the space of mobile-phone health interventions. J Biomed Inform 2012; 45(1): 184-98.

[http://dx.doi.org/10.1016/j.jbi.2011.08.017] [PMID: 219 25288]

[4] Wallace S, Clark M, White J. 'It's on my iPhone': attitudes to the use of mobile computing devices in medical education, a mixed-methods study. BMJ Open 2012; 2(4): e001099.

[http://dx.doi.org/10.1136/bmjopen-2012-001099] [PMID: 229 23627]

[5] Iwaya LH, Gomes MAL, Simplício MA, et al. Mobile health in emerging countries: a survey of research initiatives in Brazil. Int J Med Inform 2013; 82(5): 283-98.

[http://dx.doi.org/10.1016/j.ijmedinf.2013.01.003] [PMID: 234 10658]

[6] Mesquita AC, Zamarioli CM, Carvalho EC. The use of robots in nursing care practices: an exploratory-descriptive study. Online braz $\mathrm{j}$ nurs 2016; 15(3): 404-13.

[7] Fineout-Overholt E, Williamson KM, Gallagher-Ford L, Melnyk BM, Stillwell SB. Following the evidence: planning for sustainable change. Am J Nurs 2011; 111(1): 54-60.

[http://dx.doi.org/10.1097/01.NAJ.0000393062.83761.c0] [PMID: $21191236]$

[8] Santos MM, Coelho GM, Santos DM, Filho LF. Prospecção de tecnologias de futuro: métodos, técnicas e abordagens. Parcerias estratégicas 2010; 19(12): 189-230.

[9] Coelho GM. La société de la connaissance et les systèmes d'information stratégique comme appui à la prise de décision: proposition pour l'enseignement de l'Intelligence Compétitive au Brésil 2001330 f Tese (Doutorado). Marseille: Faculté des Sciences et Techniques de Saint Jérome, Université de Droit et des Sciences d'Aix - Marseille 2001.

[10] mHealth: New horizons for health through mobile technologies: second global survey on eHealth 2011. Available from: http://www.who.int/goe/publications/goe_mhealth_web.pdf

[11] De Silva L, Diamantidis CJ, Prakash D, Zuckerman M, Weir MR, Weir MR. Usability of mobile technology to screen for drug-drug interactions in kidney transplant patients. Am J Nephrol 2014; 40(2): 97-104. 
[http://dx.doi.org/10.1159/000364910] [PMID: 25059 671]

[12] Ferretti A, Valeo L, Mazza D, et al. Smartphone versus knee ligament arthrometer when size does not matter. Int Orthop 2014; 38(10): 2197-9.

[http://dx.doi.org/10.1007/s00264-014-2492-x] [PMID: 25005 461]

[13] Eftekhar B. A smartphone app to assist scalp localization of superficial supratentorial lesions. World Neurosurg 2016; 85: 359-63.

[http://dx.doi.org/10.1016/j.wneu.2015.09.091] [PMID: 26455 767]

[14] Gustavell T, Sundberg K, Frank C, et al. Symptoms and self-care following pancreaticoduodenectomy: Perspectives from patients and healthcare professionals - Foundation for an interactive ICT application. Eur J Oncol Nurs 2017; 26: 36-41. [http://dx.doi.org/10.1016/j.ejon.2016.12.002] [PMID: 28069 150]

[15] Hwang H. Electronic wound monitoring after ambulatory breast cancer surgery: Improving patient care and satisfaction using a smart phone app. BCMJ 2016; 58(8): 448-53. Epub

[16] Lorenzo-Zúñiga V, Moreno de Vega V, Marín I, Barberá M, Boix J. Improving the quality of colonoscopy bowel preparation using a smart phone application: a randomized trial. Dig Endosc 2015; 27(5): 590-5. [http://dx.doi.org/10.1111/den.12467] [PMID: 25708 251]

[17] Mundi MS, Lorentz PA, Grothe K, Kellogg TA, Collazo-Clavell ML. Feasibility of Smartphone-Based Education Modules and Ecological Momentary Assessment/Intervention in Pre-bariatric Surgery Patients. Obes Surg 2015; 25(10): 1875-81.

[http://dx.doi.org/10.1007/s11695-015-1617-7] [PMID: 25702 141]

[18] Tarakji KG, Wazni OM, Callahan T, et al. Using a novel wireless system for monitoring patients after the atrial fibrillation ablation procedure: the iTransmit study. Heart Rhythm 2015; 12(3): 554-9. [http://dx.doi.org/10.1016/j.hrthm.2014.11.015] [PMID: 254 60854]

[19] Thomale UW. Intracranial ventricular catheter placement with a smartphone assisted instrument. Methods Mol Biol 2015; 1256: 405-17.

[http://dx.doi.org/10.1007/978-1-4939-2172-0_27] [PMID: 25626 554]

[20] Zhang MW, Ho RC, Hawa R, Sockalingam S. Pilot implementation and user preferences of a Bariatric After-care application. Technol Health Care 2015; 23(6): 729-36.

[http://dx.doi.org/10.3233/THC-151025] [PMID: 26409 513]

[21] Zhang MW, Ho RC, Cassin SE, Hawa R, Sockalingam S. Online and smartphone based cognitive behavioral therapy for bariatric surgery patients: Initial pilot study. Technol Health Care 2015; 23(6): 737-44. [http://dx.doi.org/10.3233/THC-151026] [PMID: 26409 514]

[22] Stomberg MW, Platon B, Widén A, Wallner I, Karlsson O. Health information: what can mobile phone assessments add? Perspect Health Inf Manag 2012; 9(Fall): 1-10.

[PMID: 23209 453]

[23] Pfaeffli L, Maddison R, Jiang Y, Dalleck L, Löf M. Measuring physical activity in a cardiac rehabilitation population using a smartphone-based questionnaire. J Med Internet Res 2013;22; 15(3): e61.

[24] Parvizi D, Giretzlehner M, Dirnberger J, et al. The use of telemedicine in burn care: development of a mobile system for TBSA documentation and remote assessment. Ann Burns Fire Disasters 2014; 27(2): 94-100

[PMID: 26170 783]

[25] Fu H, McMahon SK, Gross CR, Adam TJ, Wyman JF. Usability and clinical efficacy of diabetes mobile applications for adults with type 2 diabetes: A systematic review. Diabetes Res Clin Pract 2017; 131 : 70-81.

[http://dx.doi.org/10.1016/j.diabres.2017.06.016] [PMID: 286 92830]

[26] Wu Y, Yao X, Vespasiani G, et al. Mobile App-Based Interventions to Support Diabetes Self-Management: A Systematic Review of Randomized Controlled Trials to Identify Functions Associated with Glycemic Efficacy. JMIR Mhealth Uhealth 2017; 5(3): e35. [http://dx.doi.org/10.2196/mhealth.6522] [PMID: 28292 740]

[27] Peng W, Yuan S, Holtz BE. Exploring the Challenges and Opportunities of Health Mobile Apps for Individuals with Type 2 Diabetes Living in Rural Communities. Telemed J E Health 2016; 22(9): 733-8.

[http://dx.doi.org/10.1089/tmj.2015.0180] [PMID: 26982 017]

[28] Portz JD, Vehovec A, Dolansky MA, Levin JB, Bull S, Boxer R. The Development and Acceptability of a Mobile Application for Tracking Symptoms of Heart Failure Among Older Adults. Telemed J E Health 2018; 24(2): 161-5.

[http://dx.doi.org/10.1089/tmj.2017.0036] [PMID: 28696 832]

[29] Maijala V, Tossavainen K, Turunen H. Health promotion practices delivered by primary health care nurses: Elements for success in Finland. Appl Nurs Res 2016; 30: 45-51.

[http://dx.doi.org/10.1016/j.apnr.2015.11.002] [PMID: 27091 252]

\section{9 de Sousa et al.}

This is an open access article distributed under the terms of the Creative Commons Attribution 4.0 International Public License (CC-BY 4.0), a copy of which is available at: (https://creativecommons.org/licenses/by/4.0/legalcode). This license permits unrestricted use, distribution, and reproduction in any medium, provided the original author and source are credited. 